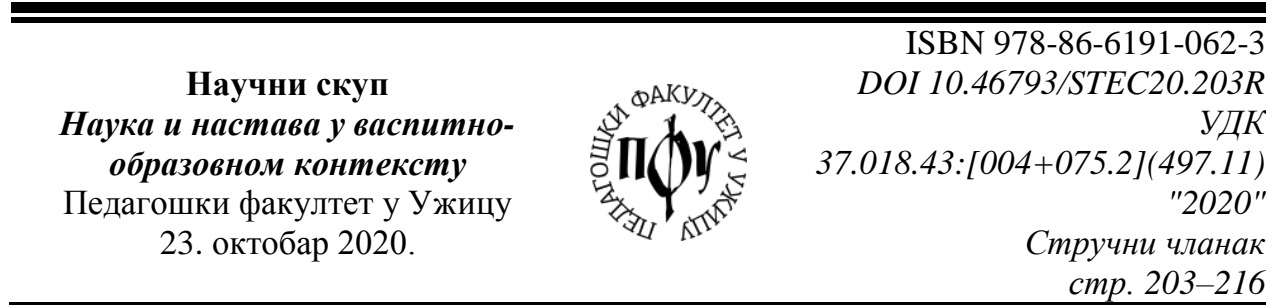

\author{
Branislav M. Ranđelović ${ }^{*}$ \\ University of Kosovska Mitrovica, Faculty of Teachers Education, Leposavić \\ Elizabeta Karalic ${ }^{*}$ \\ Institute for Education Quality and Evaluation, Belgrade \\ Danijela Đukić* \\ Institute for Education Quality and Evaluation, Belgrade
}

\title{
THE DIGITALIZATION OF THE LEARNING PROCESS IN SERBIA DURING THE COVID-19 CRISIS
}

\begin{abstract}
The COVID-19 crisis significantly disturbed the teaching process in Serbia. The subject of this research is the reaction and response of Serbian educational system during this crisis. The aim of this paper is the analysis of modifications of the teaching process and distance learning activities in primary and secondary schools, and teaching using the national public television service.The use of the method of content analysis, legal acts in the field of education adopted during the state of emergency in Serbia, decisions and instructions for the implementation of teaching, the manner of implementation of teaching, as well as the results of research on distance learning were investigated. Measures and activities for improving the digital alternative for future educational practice are proposed.
\end{abstract}

Keywords: digitalization, distance learning, online education.

\section{COVID-19 CRISISAND THE EDUCATIONAL SYSTEM IN THE REPUBLIC OF SERBIA}

It was obvious that it will be very difficult to finish the teaching process for the school year, bearing in mind the increasing number of COVID-19 cases in the world and speeading of the virus ${ }^{1}$, in January 2020. UNESCO stated that, as of March 12, forty-six countries on five different continents have announced school closures to

\footnotetext{
* branislav.randjelovic@pr.ac.rs

*ekaralic@ceo.gov.rs

*ddjukic@ceo.gov.rs

1 World Health Organization: Globally, as of 3:59 pm CEST, 17 August 2020, there havebeen 21,549,706 confirmed cases of COVID-19, including 767,158 deaths, reported to WHO.
} 
Ranđelović, B., Karalić, E., Đukić, D.: The Digitalization of the Learning Process...

Научни скуп „Наука и настава у васпитно-образовном контексту” • стр. 203-2016

contain the spread of COVID-19. ${ }^{2}$ Conditions were unusual and irregular and required the Government and the Ministry of Education, Science and Technological Development to make decisions and implement measures.

The Decision of the Government of the Republic of Serbia on the suspension of teaching in higher education institutions, secondary and primary schools and the regular work of preschool education institutions, ${ }^{3}$ was adopted in accordance with the Decision on declaring a state of emergency ${ }^{4}$ and the Decree on measures during a state of emergency ${ }^{5}$ the Ministry of Education, Science and Technological Development of the Republic of Serbia. Thus, the entire education system in the country had to react appropriately. Since March 15,2020, direct work with children in preschool institutions, students in all primary and secondary schools, as well as students in institutions of higher education, has been temporarily suspended ${ }^{6}$, and distance learning (Imel, 1998) was organized. The Ministry of Education, Science and Technological Development, the Institute for the Improvement of Education and the Institute for Education Quality and Evaluation adopted and started to implement a complex set of activities, consisting of a large number of different programs and digital methods of teaching and learning. Main focuswas on distance learning (Moore et al., 2011). Distance learning is a process where teachers present the teaching content through the application of different methods and strategies and using multimedia and information and communication technologies to provide teaching work with students. It was expected that this type of learning and digital content in teaching process will contribute the most (Mandić et al., 2013). Distance learning is free of spatiotemporal limits and thanks to the expansion of technology, the possibilities for teaching work are challenging, numerous and dynamic.

\section{THE LEGAL BASIS OF DIGITALIZATION OF THE LEARNING PROCESS IN SERBIA}

On March 10, 2020 the Government of the Republic of Serbia adopts the Decision on the declaration of COVID-19 disease caused by infectious virus SARS-

${ }^{2}$ https://en.unesco.org/covid19/educationresponse.

${ }^{3}$ Decision on suspension of work of pupil and student standard institutions founded by the Republic of Serbia ("Official Gazette of RS", No. 32/2020) and Decision on suspension of teaching in higher education institutions, secondary and primary schools and regular operation of preschool education institutions ("Official Gazette of RS", No. 30/2020).

${ }^{4}$ Decision on declaring a state of emergency "Official Gazette of RS", No. 29 of March 15, 2020.

${ }^{5}$ Date 15.03.2020. yr. The Operational Plan for the Continuation of the Work of Schools in Difficult Conditions was adopted with a distance learning program for primary and secondary school students, which was published on the Ministry's website.

${ }^{6}$ Decision on the suspension of teaching in higher education institutions, secondary and primary schools and the regular work of preschool education institutions ("Official Gazette of the RS", No. 30/2020). 
Ranđelović, B., Karalić, E., Đukić, D.: The Digitalization of the Learning Process...

Научни скуп „Наука и настава у васпитно-образовном контексту” • стр. 203-2016

CoV-2. ("Official Gazette of the RS", br. 23/2020). On March 15, the Government additionally adopts the Decision of the Government of the Republic of Serbia on the suspension of teaching in higher education institutions, secondary and primary schools and the regular work of preschool education institutions ("Official Gazette of the RS", No. 30/2020) that proclaims the measure of suspension of teaching in higher education institutions, secondary and primary schools and the regular work of preschool education institutions for as long as the danger of spreading the infectious disease COVID-19 persists. Related to this measure, the Ministry of Education, Science and Technological Development adopted the Operational plan for the continuation of the work of schools in challenging conditions with a distance learning program for primary and secondary school students, which was published on the Ministry's official webpage. The Operational plan is based on the Law on the Educational System Foundations, which states that teaching can be performed both as teaching at home and as distance learning. ${ }^{7}$

Operational plan for the continuation of the work of schools is a guide for principals, teaching associates, teachers and homeroom teachers for implementation of educational work by distance learning, which began on March 17, 2020. Depending on the level of education, the following guidelines are provided:

- Educational content for distance learning broadcast on channel of Serbian Radio-Television (RTS channel 3) for primary school students.

- Educational content for distance learning broadcast of RTS Planeta channel of Serbian Radio-Television for secondary school students.

- Online platforms to support distance learning.

- Operational plan for the schools to organize, implement and monitor distance learning.

- Monitoring student progress during the distance learning period.

- Records on the implementation of distance educational activities.

- Additional forms of student support in distance learning.

- Information and communication.

All schools were obliged to place a banner on the school website with a link to the www.rasporednastave.gov.rs website and notifications related to the broadcasting of lectures on RTS. In order to support students in learning, a horizontal exchange between teachers of the same school and between schools was called for, in order to make the highest quality content available to students.

${ }^{7}$ ZOSOV, 2018: 76 . 
Ranđelović, B., Karalić, E., Đukić, D.: The Digitalization of the Learning Process...

Научни скуп „Наука и настава у васпитно-образовном контексту” • стр. 203-2016

To ensure the continuity of education, UNICEF has provided support to the Ministry of Education through a number of activities. In the field of primary and secondary education, UNICEF assisted teachers in the development of materials broadcast on TV channels and the national online learning platform, and contributed to improving the digital competencies of educators and teachers for organizing distance learning.

\section{NATIONAL TELEVISION AND ONLINE PLATFORMS IN SERVICE OF THE TEACHING PROCESS}

At the beginning, the Ministry of Education, Science and Technological Developmentmade an important decision regarding the recording of lectures and teaching content, which would be broadcast on state television. The reaction of the educational system was separate, but so was the courage of a number of teachers, who were brave enough to appear "on stage", speaking in front of audience of millions (around 700.000 students and over 1.000.000 parents/guardiansin Serbia ${ }^{8}$ ), and started very important work for the future of children in Serbia. Distance learning is not an invention of our time, it has been around since the 18th century and first correspondence schools, through the use of radio and television to multimedia computer systems and interactive television of the 21 st century (Moore et al., 2011). Nevertheless, footage from the national television on March 17, 2020, such as the one shown in the Figure 1, will go down in the history of Serbianeducational system.

The process of distance teaching was designed in accordance with the possibilities of our educational system, but also with very short time available. However, additional steps and additional activities were necessary to accelerate the implementation of this process. One of them is webpage www.raspored nastave.gov.rs, where all RTS class schedules are available to the students in Serbia.

\footnotetext{
${ }^{8}$ The website of the Republic Bureau of Statistics of the Republic of Serbia states that it is at the end of the 2018/2019 school year. A total of 524,518 students attended primary school, and 249,455 students attended secondary school.
} 
Ranđelović, B., Karalić, E., Đukić, D.: The Digitalization of the Learning Process... Научни скуп „Наука и настава у васпитно-образовном контексту” • стр. 203-2016

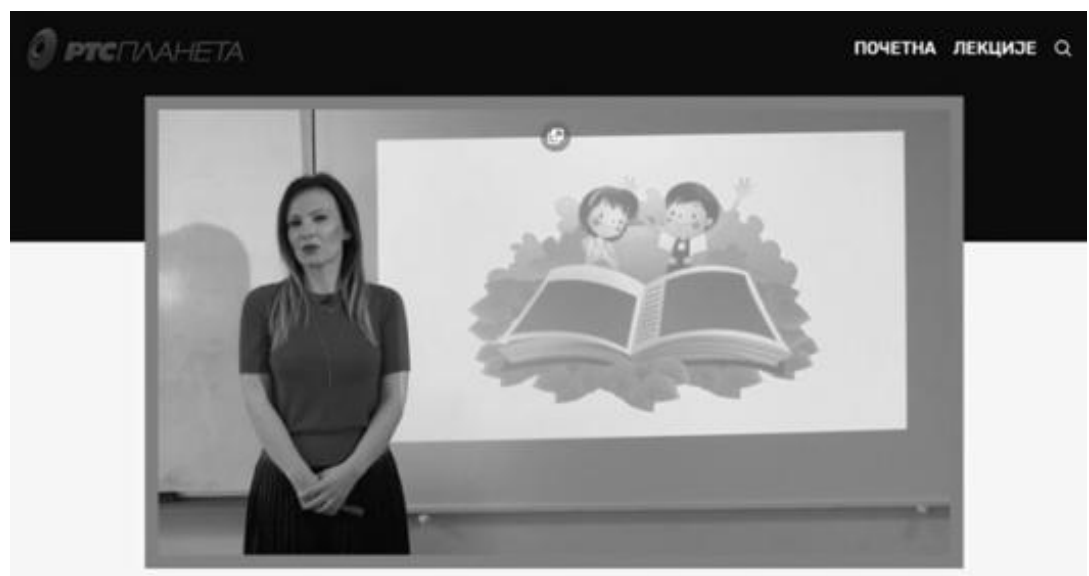

Fig. 1. The first online class on 17.03.2020.

Therefore, all students, teachers and parents werecontinuously informed about each segment of teaching, which was covered by educational content on state television. The following figure is from the https://www.rasporednastave.gov.rs/ website (see Figure 2) where a schedule of broadcasting educational content for primary and secondary school students on TV channels RTS 2 and RTS 3 was publicly available.

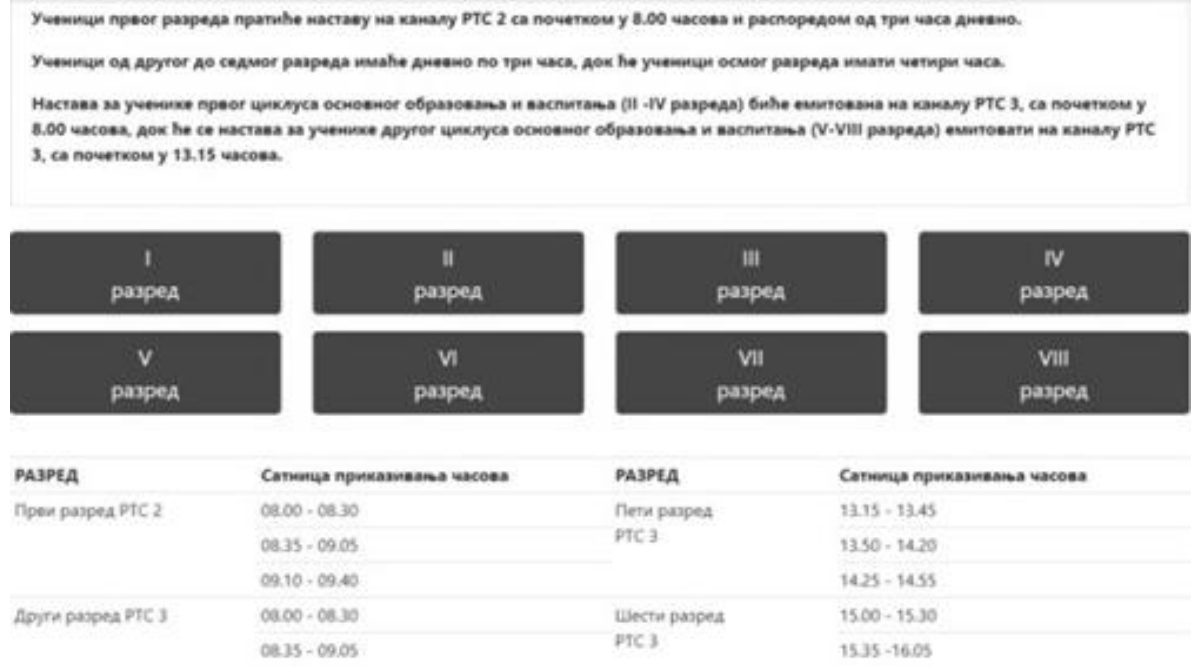

Fig.2. Website with class schedule and timetable 
Ranđelović, B., Karalić, E., Đukić, D.: The Digitalization of the Learning Process... Научни скуп „Наука и настава у васпитно-образовном контексту” • стр. 203-2016

The next Figure 3. is one screenshot from website of the Ministry of Education, Science and Technological Development and it shows a detailed class schedule for the first grade of primary school from March $23^{\text {rd }}$ to March 27, 2020.

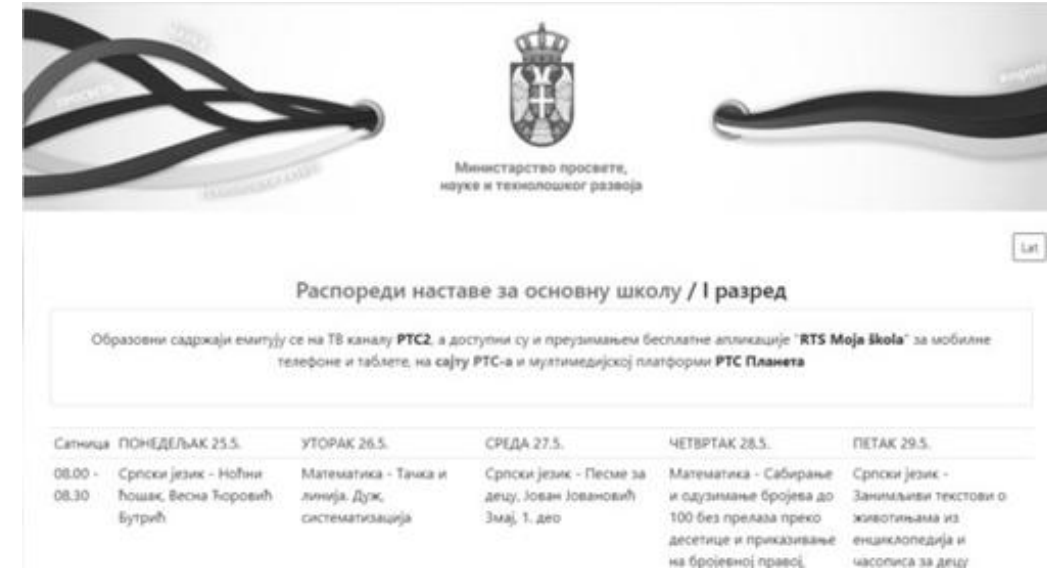

Fig. 3. Website of the Ministry of Education, Science, and Technological Development - Contents and details on lectures

Teachers have had the opportunity to work directly with children, using other digital media (Randjelovic et al., 2019), e.g. the national platform for online learning www.mojaskola.gov.rs (see Figure 4). They could use some televised contents, but also teach contents that weren't sufficiently covered on the television.

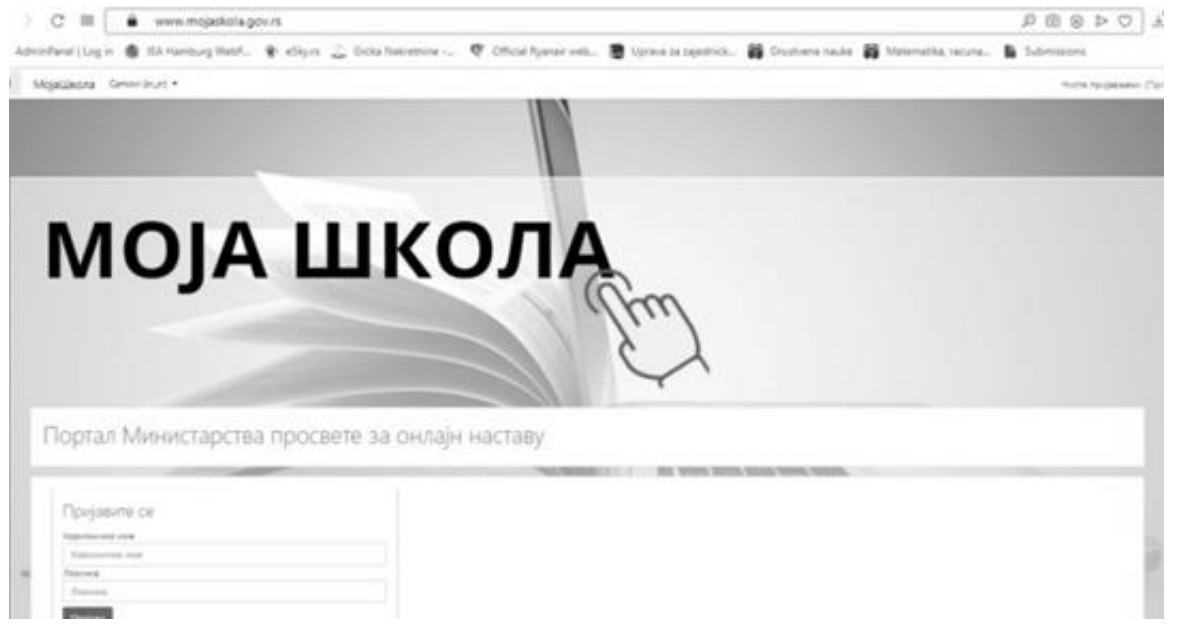

Fig. 4. National online learning web-platform www.mojaskola.gov.rs 
Ranđelović, B., Karalić, E., Đukić, D.: The Digitalization of the Learning Process... Научни скуп „Наука и настава у васпитно-образовном контексту” • стр. 203-2016

The interactivity in teachingwas additionally encouraged by the establishment of the national platform for online learning www.mojaskola.gov.rs. Interactivity was stimulated through tests on the portal, and thus also contributed to the self-regulation process in learning. The website www.mojaskola.gov.rs also contains various recommendations for online communication between teachers and students.

A learning management system "Moja skola" (My School), based on Moodle (see Figure 5), has also been installed, and managed by the Ministry of Education, Science and Technological Development. Digital content on the portal was additionally contributed by general education and subject teachers, employed in primary and secondary schools, whoprepared and submitted testson a volunteer basis.

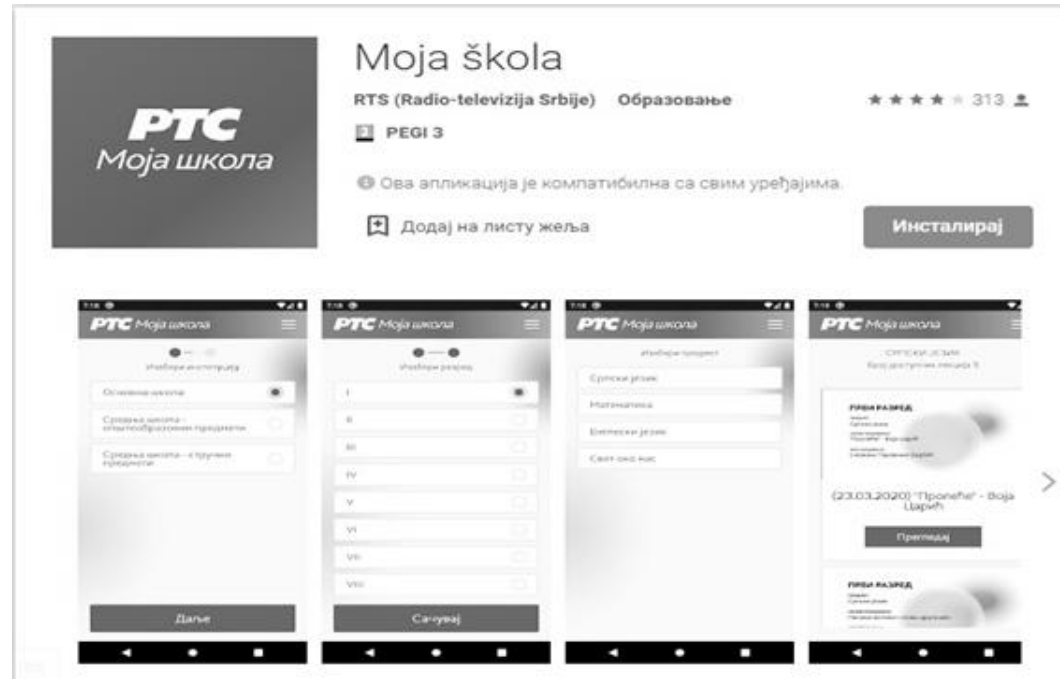

Fig. 5. Free Android application "RTS Mojaskola” available on Google Play Store

These tests were then placed on a platform. Professional societies made their contribution delegating teachers for cooperation, and thus contributing to the sustainability.

Educational contents were broadcasted on TV channels, and they were also available through the free application "RTS Mojaskola" for mobile phones and tablets (see Figure 6). 
Ranđelović, B., Karalić, E., Đukić, D.: The Digitalization of the Learning Process...

Научни скуп „Наука и настава у васпитно-образовном контексту” • стр. 203-2016

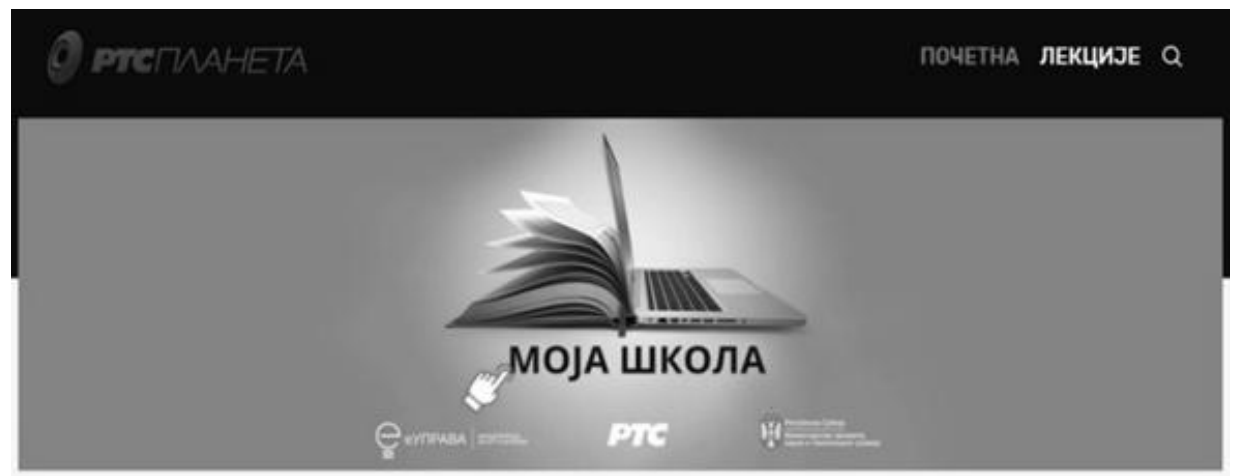

\section{ЛЕКЦИЈЕ}

Fig. 6. Multimedia website https://mojaskola.rtsplaneta.rs with teaching materials

Some kind of digital archive of all broadcasted content and teaching materials, on multimedia platform (https://mojaskola.rtsplaneta.rs) is a form of additional support for students.

At the same time, an intensive preparation of teachers was carried out, with aim to educate them on how to prepare educational materialsat home. UNICEF Serbia procured and donated a number of licenses for "Camtasia", software for recording and preparing teaching materials at home and, as of early days of April, home prepared materials started to be broadcast on television.

\section{COMMUNICATION AND COOPERATION BETWEEN TEACHERS, STUDENTS AND PARENTS}

During the distance learning process, it was necessary for teachers to communicate almost daily with their students and student's parents. The teachers were obliged, in cooperation with homeroom teachers, to give students additional learning instructions after the content was broadcasted on RTS channels (additional presentations or practice problems in workbooks, homework essays, analyses, presentations, illustations, drawings, reports on mini-projects etc.). Students were encouraged to send homeworks to their teachers, but teachers were expected to discuss with the students and parents other procedural and technical details

\footnotetext{
${ }^{9}$ UNICEF, 2020: 5 .
} 
Ranđelović, B., Karalić, E., Đukić, D.: The Digitalization of the Learning Process...

Научни скуп „Наука и настава у васпитно-образовном контексту” • стр. 203-2016

necessary for the teaching process. There are various free web-platforms for this purpose (Zoom, Skype, Microsoft Teams, Google Meet, Google Classroom...) ${ }^{10}$. Additionally, there were applications and social networks (Facebook, Messenger, Viber, WhatsApp...), and e-mail. In retrospect, we can now say that, Viber application, Zoom platform and e-mail were definitely the most frequently used. ${ }^{11}$

The main purpose of Zoom application is online meetings and is available for free. Thanks to the Viber company, using the Viber application and the Viber Community service was enabled, providing better group communication and information exchange, which was extremely useful in those specific circumstances. Email communication was also very effective for sending various files, homework, as well as for other forms of communication within groups with a finite number of users. Many teachers used e-mail groups for communication with students and parents.

Another application improved communication, and that is, so called, electronicrecord book ("esDnevnik"). The project of electronic record book implementation began with a pilot project in 2017/2018. school year. During the 2018/2019. school year, all schools participated in the main project. ${ }^{12}$ Now it has a significant role. After its upgrade and improvement of itsfunctionality for formative monitoring and evaluation of students in the "esDnevnik", from 02.04.2020. parents wereable to follow all the formative grades of students (https://moj.esdnevnik.rs/).

The COVID-19 crisis has led to new forms of evaluating students' educational achievements. The Ministry of Education, Science and Technological Development, the Institute for Education Quality and Evaluation, the Office for IT and Electronic Administration and the "Comtrade" company provided additional support to students, teachers and schools with standardized tests in an online environment. The "Self-assessment of Knowledge 2020" test is the first online test in the Republic of Serbia for a whole generation of primary school 8th graders. Tests for self-assessment of knowledge are designed so that students have the opportunity to test their knowledge two months before the final exam at the end of primary education by taking three tests that include a total of sevensubjects (Serbian or other mother tongue, mathematics, physics, geography, history, chemistry and biology). In this way, it was possible to develop self-regulated learning, above all through the self-assessment of current level of students' knowledge and planning the next steps in learning.

In addition to self-assessment of knowledge, students had access to tests and test solutions from previous final exams on the website www.mojaucionica.gov.rs as a form of support for the exit examination by distance learning.

\footnotetext{
${ }^{10} \mathrm{https} / / /$ www.danas.rs/drustvo/skoro-60-odsto-djaka-nije-gledalo-tv-casove/

${ }^{11}$ The results of a survey of 15,000 teachers on the realization of the educational process through distance learning have been published on the website of the Institute for the Advancement of Education and Upbringing. VIBER was used by $37.5 \%$ of the surveyed teachers (http://www.komocetis.f.bg.ac.rs/projekat.php?p=115).

${ }^{12} \mathrm{http} / / /$ www.mpn.gov.rs/elektronski-dnevnik-esdnevnik/
} 
Ranđelović, B., Karalić, E., Đukić, D.: The Digitalization of the Learning Process...

Научни скуп „Наука и настава у васпитно-образовном контексту” • стр. 203-2016

\section{VULNERABLE GROUPS AND DISTANCE LEARNING}

In order to monitor the inclusion of students from vulnerable groups in those specific circumstances, a study entitled "Monitoring the manner of participation and learning process of students from vulnerable groups during the implementation of educational work through distance learning" was performed. For research purposes, the Ministry of Education, Science and Technological Development of the Republic of Serbia and UNICEF Serbia prepared additional questionnaire, which was also distributed to all public schools in Serbia. The Institute of Psychology was entrusted with the analysis and interpretation of the collected data. ${ }^{13}$

Of the 1753 institutions to which the questionnaire was sent, 1672 completed it. The obtained data refer to 746,467 students enrolled in the 2019/2020 school year, which is $93 \%$ of allenrolled students. Schools are divided into three groups: primary schools, secondary schools andschools for education of students with disabilities. In primary and secondary schools, the coverage of students with distance learning is $99 \%$, and in schools for education of students with disabilities the coverageis $93 \%$. This applies both to watching TV lectures and using online learning platforms, as well as using alternative forms of distance learning. However, there are big differences between the types of schools regarding their involvement in distance learning, as well as in terms of their dominant communication channels. TV lectures were mostly watched by primary school students, followed by almost two thirdshigh school students and about a quarter of students enrolled in schools for education of students withdisabilities. On the other hand, online learning platforms were used by almost all high school students, $85 \%$ of primary school students, and onlyslightly more than a half of students from schools for the education of students with disabilities. The lower usage of TV and online teaching in schools for students with disabilities was bridged by greater reliance on alternative forms of support, where almost every third student was educated in this alternative way. Research has shown that the biggest challenges in the implementation of distance learning for primary and secondary school students were technical resources (unavailability of Internet, lack of a suitable device), but also the lack of parental support.

The Institute for Pedagogical Research conducted two research projects related to distance learning and mental health of children and youth during the pandemic. The aim of the first project was to describe and understand the dynamics of distance learning process from the perspective of various participants in the educational system. The aim of the second research was to examine the fears and behaviors of parents and their children during the pandemic.

${ }^{13}$ Monitoring the methods of participation and learning process of students from vulnerable groups during the implementation of educational work through distance learning [in Serbian] 2020: 2 . 
Ranđelović, B., Karalić, E., Đukić, D.: The Digitalization of the Learning Process... Научни скуп „Наука и настава у васпитно-образовном контексту” • стр. 203-2016

The Teachers' Union of the Republic of Serbia conducted a research "Experiences and attitudes of employees in primary schools towards implementation of online teaching". The research was conducted between May and June 2020, with the aim of collecting the views and experiences of homeroom and subject teachers in primary schools on the implementation of online education, i.e. distance learning. Prior to the proclamation of state of emergency, only 57 teachers had taught in this way.

Regarding methods of conducting distance learning, the most used tools and platforms are Viber Community (347 respondents) and Google Classroom (243 respondents), while others were used to a lesser extent. Survey respondents stated that the most common difficulty was students' lack of independence in their work, lack of internet and necessary technical conditions for students, parents' lack of competency, irresponsibility and disinterest, insufficient students' digital competencies, difficulty in reviewing papers in an electronic form, lack of direct communication and lack of feedback follow-up from students.

OMC Survey on online and distance learning was conducted throughout Europe from April 9th to May 10th 2020 and surveyed 4,859 respondents, of whom $86 \%$ were teachers and school principals. Respondents believe that online learning will probably become, in some way, an integral part of regular teaching. For twothirds of respondents, school closures led to their first experience with online teaching, which was both positive and challenging. As the most pleasant surprise from online teaching, $38 \%$ of respondents state innovations (freedom to experiment with teaching practice), then flexibility, broad range of digital tools, accessibility of platforms, materials and resources, and increased autonomy and motivation among students. Fewer respondents chose the engagement and enjoyment of the students as a pleasant surprise from online teaching. The most frequently mentioned challenge / problem in this new situation was the accessibility of technology (computers, software, stable internet connection, etc.), either for student or teacher. Another challenge was the increased workload, stress, student support, student motivation and social inclusion of vulnerable students in the online teaching process. Respondents also stated that they encountered problems of monitoring student achievement and difficulties in communicating with students.

Establishing a quality system is essential in current circumstances. The Institute for Education Quality and Evaluation,in cooperation with the Ministry of Education, Science and Technological Development has prepared a framework for assessing the capacity of primary and secondary schools to organize distance education in case of suspension of direct work with students ${ }^{14}$, to be a starting point for defining the quality standards of the educational institutions' work, and to help create indications for monitoring and evaluation of the schools' work, as well as making recommendations for educational policies. Ministry of Education also

\footnotetext{
${ }^{14}$ https://ceo.edu.rs/wp-content/uploads/2020/08/Okvir-obrazovanje-na-daljinu-082020.pdf.
} 
Ranđelović, B., Karalić, E., Đukić, D.: The Digitalization of the Learning Process...

Научни скуп „Наука и настава у васпитно-образовном контексту” • стр. 203-2016

reacted, by publishing documents, rules and procedures about quality of distance learning education in primary schools. ${ }^{15}$ The analysis of indicators for monitoring and evaluating the work of schools during the COVID-19 crisis will be the subject of future research.

\section{CONCLUSIONS AND IMPLICATIONS FOR PRACTICE}

This paper deals with the response and reaction of the educational system of the Republic of Serbia to the COVID-19 crisis, regarding teaching and distance learning activities in primary and secondary schools. Lectures broadcast via public television service were evaluated, and other services used in the function of distance learning. Based on this consideration, we can conclude that:

The Ministry of Education, Science and Technological Development of the Republic of Serbia reacted to the COVID-19 crisis in a satisfactory manner at the very beginning of the crisis, by switching to distance learning. The system did notallow children in primary and secondary schools to waste time and miss out on lessons. Teaching using public television service started immediately and it quickly reached a significant level of quality.

The Ministry opened the information channels between students, teachers and parents, as well as parents and the educational system itself, on the official website www.mpn.gov.rs, then on the website www.rasporednastave.gov.rs;

Web portals www.mojaskola.gov.rs, www.mojaskola.rtsplaneta.rs and the Android application MojaSkola additionaly contributed to the quality of distance learning. It is expected that those portals will continue to work and offer appropriate learning contents, so it will be some kind of an open digital alternative for our education.

Communication between students and teachers reached a much higher level, especially thanks to web portals and platforms, as well as social networks of a general type and other ways of communication based on modern technologies. Professional development of teachers should be oriented to encourage them to adopt and maintain these ways of communication even in regular circumstances.

Some IT companies made significant impact in this process, offering their hardware and human resources available to the educational system of the Republic of Serbia. We should hope that other domestic or foreign companies in Serbia will demonstrate their corporate responsibility and put additional effort and funds into the educational sector, where concrete results can be seen very quickly.

\footnotetext{
${ }^{15}$ https://www.paragraf.rs/propisi/pravilnik-uslovi-kvalitet-nastave-na-daljinu-za-osnovneskole.html.
} 
Ranđelović, B., Karalić, E., Đukić, D.: The Digitalization of the Learning Process... Научни скуп „Наука и настава у васпитно-образовном контексту” • стр. 203-2016

Based on the decision makers' priorities, we suggest that a new strategy in this field should be developed in the forthcoming period, according to the following seven important factors:

(a) reliable communication infrastructure,

(b) suitable digital learning resources,

(c) web based user-friendly learning tools,

(d) contemporary and more effective learning methods,

(e) teachers organizations,

(f) effective support services for teachers and learners,

(g) close cooperation between the Government, enterprises and schools.

In hope that distance learning will be further more integrated, evaluated, and improved in the educational system of Serbia, our work provides suggestions for future teaching practice, in addition to a systematic overview of previous activities and results of distance learning.

\section{References}

Börje Holmberg (2005). The Evolution, Principles and Practices of Distance Education, Studien und Berichte der Arbeitsstelle Fernstudienforschung der Carl von Ossietzky Universität Oldenburg Arbeitsstelle Fernstudienforschung, part 11.

Imel, S. (1998). Myths and realities of distance learning. Columbus. Ohio: ERIC Clearinghouse on Adult, Career, and Vocational Education/ Ohio State University. (Eric Document Reproduction Service No. ED 414 446).

Law on the Basics of the Education System (Official Gazette of RS, No. 88/2017, 27/2018 - other law, 10/2019, 27/2018 - other law and 6/2020).

Mandić, D. \& Ristic, M. (2006). WEB portals and distance education in the function of raising the quality of teaching. Beograf: Mediagraf.

Mandic, D. \& Mandic, A. (2013). Innovations in Modern Education and Teachers Competences. Asian Journal of Education and e-Learning, 1(1), 70-88.

Moore, J. L., Dicskon-Deane, C. \& Galyen, K. (2011). E-Learning, online learning, and distance learning environments: Are they the same?. The Internet and Higher Education, 14(2), 129-135.

Praćenje načina učešća i procesa učenja učenika iz osetljivih grupa tokom ostvarivanja obrazovno-vaspitnog rada učenjem na daljinu, izveštaj na osnovu istraživačkih nalaza (2020). Beograd: Ministarstvo prosvete, nauke i tehnološkog razvoja RS, UNICEF, Institut za Psihologiju. 
Ranđelović, B., Karalić, E., Đukić, D.: The Digitalization of the Learning Process...

Научни скуп „Наука и настава у васпитно-образовном контексту” • стр. 203-2016

Randjelovic, B. Stanojevic, D. \& Minic, S. (2019). Analysis of framework of digital competences for teachers in Serbia and teachers in European Union. In Lecture on Sci. Conf. Inovative approach to education: situation, dilemas and perspectives, May 31, 2019, University of K. Mitrovica, Faculty of Teacher Education Leposavic, Proc. of Papers, 35-43.

Report about distance education in Republic of Serbiain emergency state (2020). Ministary of Educaton Science and Technological Development of Republic of Serbia.

Republic Statistical Office of the Republic of Serbia. Retrieved August 17, 2020 from the World Wide Web https://www.stat.gov.rs/sr-latn/oblasti/obrazovanje/.

Results of the research "Experiences and attitudes of employees in primary schools on the implementation of online teaching" (2020). Teachers' Union of the Republic of Serbia. Retrieved August 17, 2020 from the World Wide Web https://www.surs.org.rs/images/dokumenti/2020/08/Iskustva\%20i\%20stavovi\%20z aposlenih\%20u\%200S\%20o\%20realizaciji\%20online\%20nastave-rezultati.pdf.

UNICEF (2020). UNICEF's response to the COVID-19 pandemic in Serbia.

World Health Organization, WHO Coronavirus Disease (COVID-19) Dashboard. Data last updated: 2020/8/17, 3:59 pm CEST (taken 17.08.2020. at 19.13)

\section{Бранислав М. Ранђеловић}

Универзитет у Косовској Митровици, Учитељски факултет, Лепосавић

\section{Елизабета Каралић}

Завод за вредновање квалитета образовања и васпитања, Београд

Данијела Ђукић

Завод за вредновање квалитета образовања и васпитања, Београд

\section{ДИГИТАЛИЗАЦИЈА ОБРАЗОВАНОГ ПРОЦЕСА У СРБИЈИ TOКОМ COVID-19 КРИЗЕ}

\section{Резиме}

Криза COVID-19 значајно је пореметила наставни процес у Србији. Предмет овог истраживања је реакција и одговор српског образовног система током ове кризе. Циљ овог рада је анализа модификација наставног процеса и активности учења на даљину у основним и средњим школама и настава преко националног сервиса јавне телевизије. Методом анализе садржаја истражени су законски акти у области образовања донети током ванредног стања у Србији, одлуке и упутства за спровођење наставе, начин извођења наставе, као и резултати истраживања о учењу на даљину. Предложене су мере и активности за унапређивање дигиталне алтернативе за будућу образовну праксу.

Кључне речи: дигитализација, учење на даљину, настава на РТС. 